\title{
Bank Resolution Plans as a Catalyst for Global Financial Reform
}

forthcoming 6 Journal of Financial Stability 2011

\author{
Emilios Avgouleas \\ School of Law \\ University of Manchester \\ Oxford Road \\ Manchester M13 9PL \\ Charles Goodhart \\ Financial Markets Group \\ London School of Economics \\ Houghton Street \\ London WC2A $2 \mathrm{AE}$ \\ Dirk Schoenmaker \\ Duisenberg School of Finance \\ Gustav Mahlerplein 117 \\ 1082 MS Amsterdam
}

\begin{abstract}
Bank Resolution Plans (Living Wills) should help with the resolution of systemically important financial institutions (SIFIs) in distress. They should be used to clarify and simplify the legal structure and make it commensurate with the functional business lines of the institution. Living Wills could also prove the right regulatory instrument to achieve two further innovations in the resolution of SIFls with cross-border presence. First, they could incorporate burden sharing arrangements between countries enabling burden sharing on an institution by institution basis. However, there would remain problems arising from the incompatibility of the laws governing cross-border bank insolvencies. Many countries are currently introducing special laws covering the resolution of SIFIs. This creates a window of opportunity to use Living Wills to introduce a second innovation: a consistent legal regime for the resolution of SIFIs across the G20 countries.
\end{abstract}

JEL: G21, G28, G33

The opinions in the article are those of the authors and not necessarily those of the School of Law, Morgan Stanley, the Financial Markets Group or the Duisenberg School of Finance. Corresponding author: C.A.E. Goodhart; E-mail: caegoodhart@aol.com; Tel: +44 (0) 207955 7555. 


\section{Introduction}

The 2007-2009 financial crisis brought into sharp focus the massive costs associated with the bail out of complex systemically important financial institutions (SIFIs), which were perceived as too-big-to-fail. The too-big-to-fail doctrine has been reinforced, if anything, by governments' handling of the current financial crisis. As a result, the most significant regulatory reform proposals have focused on the question of how to curtail the too-big-to-fail problem. Namely, how can one reduce moral hazard and rein back expectations of future bail-outs of SIFIs?

Amongst the proposals that have been advanced so far Living Wills may prove a regulatory instrument of critical importance. Its further development might allow systemically important banks to fail or, at least, to be unwound in an orderly manner without imposing disproportionate costs on the taxpayer. The objective is to put in place, ex ante, conditions that would allow a wider range of options other than having the whole bank rescued (FSA, 2009). A Living Will is a recovery and resolution plan drawn up ex ante with the purpose of using it if a bank gets into difficulties. The G20 has requested Living Wills to be completed by the top 24 global banks and 6 insurance companies (Claessens et al., 2010).

In practice Living Wills will complement the new Basel III requirements to increase capital substantially, especially for large banks, forcing them to internalise the systemic externalities they generate (Basel Committee, 2010). Higher holdings of core equity reduce the probability of failure of systemically important banks, while Living Wills reduce the impact of a possible systemic failure. Both elements can reinforce each other to reduce the too-big-to-fail problem.

In this article, we review some key elements of Living Wills and make policy recommendations for their further development. At the first stage, there should be discussions between a bank and its supervisors about forcing a bank to simplify its often opaque and very complicated structure, and winding down its operations in times of crisis. A bank will also have to make contingent funding and de-risking plans to recover its financial strength. At the second stage, credible resolution plans should be drawn up to keep a bank alive, if needed. In the case of international banks, these resolution plans could include a burden sharing mechanism for central banks (liquidity support) and ministries of finance (capital support). The burden sharing would then be agreed on an institution by institution basis. At the third stage the bank and the authorities should build a bankruptcy scenario which would highlight possible shortcomings in deposit guarantee schemes and inconsistencies between resolution and insolvency regimes. Relevant exercises would bring such inconsistencies to the forefront of attention. Thus, authorities (including lawmakers) would be forced to tackle the most critical inconsistencies. The cross-border resolution and insolvency procedure for international banks is currently a nightmare for depositors, creditors, and shareholders, but a paradise for insolvency lawyers. For this reason, all interested parties agree that further integration of national regimes should be at the top of the regulatory reform agenda. 
Since Living Wills would be drawn up by banks and authorities, banks should be the principal actors in developing their own recovery plans. Supervisors will challenge banks on the credibility of the recovery plan. This is typically done by the core supervisory college comprising the home and key host supervisors of a bank (FSF, 2009). The resolution plan should be drawn up by the authorities (supervisors, central banks and ministries of finance) from the countries represented in the core supervisory college. As the Living Will should cover the whole bank, it is necessary to have one overall Living Will rather than a string of national Living Wills lumped together.

The main purpose of Living Wills is to achieve ex ante benefits. The drawing up of a Living Will should focus the minds of the institution's management and of the supervisors as to what they should expect in the event of an institution's failure. Thus, the drawing up of a Living Will could act as a catalyst for thinking and taking action, as in the wills of individuals. For example, in real life, a pater-familias, who starts to think about handing over his estate to his off-spring (and/or surviving partner) in case of his death and drafts a will, has to assess the structure and viability of the estate itself. On the structure side, the question he should be asking is: will my children understand the 'business' and make sense of it? Moreover, does the structure allow an orderly hand-over of the different parts of the estate to the various stakeholders (children and surviving partner)? If not, the structure should better be simplified. On the viability side, the question will concern the children's ability/willingness to accept the 'business'? Is a 'fair' distribution of the estate over my children feasible? If not, it is better to divest the loss-making parts upfront.

At the fourth and final stage, Living Wills may help to persuade banks to restructure their business (namely, simplify and hive off parts of the business) and encourage supervisors to enforce desirable restructurings when banks do not act voluntarily.

Of course, the ex post effect could be less strong due to time inconsistency (Kydland and Prescott, 1977). The burial of an individual may be handled according to the script of that individual's will. However, in case of multiple deaths (for example, due to a tower inferno, earth-quake or war), authorities need to act swiftly and ignore individual wishes (namely, wills). Accordingly, in the 20072009 financial crisis, authorities across the world ignored soft arrangements, such as Memoranda of Understanding (MoUs), and acted as they saw fit to rescue the financial system, often using unconventional tools.

The article is organised as follows. In Section 2, we examine the disciplining effects of Living Wills. How can the complex structure of banks be simplified? Section 3 reviews the resolution plans. In particular, we consider the possibility of arranging burden sharing on an institution by institution basis. In Section 4, we discuss the inconsistencies between insolvency regimes and we investigate the possibility of a standard insolvency model for systemically important financial institutions. The final section concludes. 


\section{Reducing Complexity}

The corporate structure of a bank can be extremely complex with a myriad of legal entities (Kuritzkes et al., 2003; Schoenmaker and Oosterloo, 2008). In practice, separate subsidiaries are often set up to exploit tax loopholes and regulatory arbitrage opportunities. In addition, banks may use the limited liability of various (off balance sheet) legal entities to ring-fence certain risks. At the same time, the different legal entities are interwoven through multiple intra-group transactions and common operational platforms. The result is a complex structure, which is difficult to understand, and impossible to unwind at short notice during times of stress. Basically, banks try to have the best of both worlds: exploiting the benefits of the legal structure (regulatory and tax arbitrage, etc.) and taking advantage of the synergies attached to operating as an integrated group (intra-group transactions, common IT platform, etc). Faced with a complex and opaque structure, authorities have little choice but to rescue the whole bank, if needed, to minimize the systemic consequences. However, in doing so, they also reinforce the 'too-big-to-fail' effect and increase moral hazard.

One of the goals of a Living Will is to make contingency plans for times of stress. In these plans, banks should develop scenarios under which certain, less important, parts can be sold, or put into liquidation. The systemically important parts may then be rescued, although the choice of the resolution tool may be left to be made ex post (Huertas, 2010). This is only possible with a straightforward legal structure, in which the different parts are easily identified and separated. The development of Living Wills may thus lead to a simplification of legal structure. Supervisors have the power to enforce restructuring. Following the failure of the Bank of Credit and Commerce International $(\mathrm{BCCl})$, new rules ${ }^{1}$ were introduced that allow supervisors to prohibit structures that impede effective supervision. On this basis, supervisors can enforce a transparent and coherent structure. The simplification of structures - in tandem with tight limits on intra-group transactions - may ultimately lead to separately capitalized and ring-fenced subsidiaries (Arner and Norton, 2009; Cerutti et al., 2010). Standalone subsidiaries will have their own management, IT systems, payment platform, risk management, internal controls, etc. Nonetheless, if this approach is adopted not only the front-office but also the back-office would have to be split up. The operational efficiency of banking groups is primarily realised by running a single banking platform in the back-office. In the scenario of standalone subsidiaries, the question may be asked: what are the remaining synergies of being part of a single group? Furthermore, ring-fencing may lead to fragmentation of international capital flows, the one area where multinational banks have made a truly welfare enhancing contribution to the global economy (Lipsky, 2010).

Simplification of corporate structures will help supervisors to get a better overview of, and a more effective handle on, large banking groups. However, markets tend to regard the strength of a banking group as a whole, ignoring the legal structure. As witnessed in the case of Lehman Brothers in 2008

\footnotetext{
${ }^{1}$ The Basel Committee on Banking Supervision issued guidelines 'Minimum standards for the supervision of international banking groups and their cross-border establishments' in 1992, which were further refined 'The supervision of cross-border banking' in 1996. In the EU, the post-BCCI Directive (95/26/EC) deals with corporate structures.
} 
and earlier of Drexel Burnham Lambert in 1990, solvent subsidiaries of a banking group can hardly survive when the parent company or a major subsidiary is in serious trouble. The name is then contaminated in the market, and market players cease to do business with the remaining solvent parts due to reputation risk (Freshfields, 2003). So further thought needs to be given to the question whether certain key subsidiaries can survive while still bearing the old group name. ${ }^{2}$

Ar major element of recovery plans should be the development of contingent funding arrangements. Under different scenarios, including the drying up of certain funding markets, banks develop plans to fund themselves from other sources and to maintain core liquidity holdings. This induces them to have a strategy of using multiple sources of funding. If successfully implemented, banks could rely less, and at a later stage, on the lender of last resort capacity of central banks. This would reinforce market discipline.

Banks also need to adopt contingent capital plans. A first way for a bank to address a drop in its capital adequacy ratio (defined as capital to risk adjusted assets) is to reduce risk by lowering its leverage. Plans to lay off risk may, for example, extend to closing positions, selling assets, or even selling business lines. A second way is to increase share-capital. As the issuance of new equity is very difficult when a bank is in difficulties, there are proposals to use convertible bonds. The Squam Lake Report (2010), written by a group of distinguished US academics, proposed that such bonds convert to equity only if two conditions are met. The first is an official declaration by supervisors that the financial system is suffering a systemic crisis. The second is that a bank's capital ratio falls below a pre-determined threshold.

There are, however, several questions attached to this proposal. First, what would be the effect of an official declaration that a financial crisis was occurring. If that was expected to be adverse, might not such a declaration be unduly delayed? Second, what would be the required yield on such bonds, given their risk profile and possible lack of a liquid market for such instruments? Third, the announcement of conversion of a bank's bonds into equity or missing interest payments / principal repayments on subordinated debt is a forceful signal to markets that the bank is in trouble. Such announcement in itself (or even circulation of relevant rumours) could easily trigger a wholesale bank run and cause a severe drop in the bank's share price. ${ }^{3}$ So we think there is a limit to the extent that contingent capital can replace real upfront equity capital (Goodhart, 2010).

\footnotetext{
${ }^{2}$ After the collapse of Fortis in Autumn 2008, the surviving parts had difficulties in operating under the name Fortis. The Dutch subsidiary, sold to the Dutch government, was renamed Fortis Bank Nederland (and subsequently merged into ABN AMRO in July 2010). The Belgian and Luxembourg part, sold to BNP Paribas, continued under the name BNP Paribas Fortis.

${ }^{3}$ A good example is ING: doubt arose about the interest payment on the sub-ordinated debt of ING at the height of the financial crisis in Autumn 2008. Some investors questioned publicly whether ING would meet the upcoming interest payments on its sub-ordinated debt. Although ING meant to meet the next interest payment, the supervisor did not permit ING to say so as payments on sub-ordinated debt are conditional on meeting certain capital ratios at the time of payment. After a sharp drop in the share price, the supervisor gave special permission to ING to announce that it was planning to meet its upcoming interest payments.
} 
Historically, the main mechanism for contingent capital was to apply double liability to shareholders themselves (Dowd, 1992). This was commonly used in the Scottish free banking system as well as in the USA until 1929, but fell out of favour in the latter, because it did not protect the US financial system from the collapse that followed the 1929 Wall Street Crash. In this historical spirit, Admati and Pfleiderer (2010) propose increased-liability equity. Their proposal is to set aside safe assets to cover a bank's liability to 'demandable deposits'. ${ }^{4}$ The bank under this system is allowed to hold any risky assets it wants against its own equity. We are sympathetic with the idea of more equity, but the Admati-Pfleiderer proposal will put the profitability of the banking system under pressure. Maybe rightly so.

All these contingent plans need activation triggers (if liquidity or capital falls below a certain threshold, then the contingency plan kicks in) for banks to act, and failing that, for supervisors to intervene. As with the wider issue of prompt corrective action, the effectiveness of such activation triggers depends very much on the timely identification of problems and the determination of supervisors to act swiftly (Jones and King, 1995).

\section{Arranging Burden Sharing for Individual Institutions}

When a systemically important bank ${ }^{5}$ gets into difficulties, the authorities (supervisors, central banks and ministries of finance) come into play to manage the stability of the financial system. The drafting of resolution plans helps authorities to prepare for such times, just as banks prepare themselves with recovery plans. These resolution plans cover several options. The starting point is, of course, for the authorities to determine whether the failure of a troubled bank may have a systemic impact. If not then the bank should be put into liquidation (see section 4). But if the failure is deemed to be systemic what options do authorities have? The detailed description of a bank's legal structure, which should be understandable after the ex ante restructuring exercise, and the availability of data on the activities and assets of the various parts of a banking groups, should allow the authorities to decide which parts they need to keep alive for systemic purposes and which other parts may be put into liquidation or sold. Next, the authorities will initially explore private sector solutions to keep the systemic parts afloat. The transfer of parts of a bank (for example, the deposit book) to other banks is in practice very difficult. The more common approach is a merger of the troubled bank with another bank or a takeover by another bank. In fact, at the early stages of the crisis both the US and the UK authorities followed this approach for the rescue of Bear Stearns, Merrill Lynch and Halifax Bank of Scotland, which were respectively taken over by JP Morgan, Bank of America and Lloyds Bank. This

\footnotetext{
${ }^{4}$ The Admati-Pfleiderer proposal goes back to the origins of banking when obligations where fully covered with safe assets. The Wisselbank, founded in 1609 in Amsterdam, and the Riksbank, founded in 1668 in Sweden, started off with full backing of fiduciary money by bullion reserves. As such $100 \%$ reserve banking was unprofitable, fractional reserve banking became the norm. While increasing profitability, fractional reserve banking also increases the instability of the banking system.

${ }^{5}$ Note that we do not provide a definition of a systemically important financial institution. The systemic impact of a bank failure depends very much on the circumstances. The failure of a bank in normal times may well be possible without systemic ramifications (for example, Barings in 1995), while the failure of the same bank in times of stress may generate large systemic effects.
} 
development raised, in the process, serious objections by the acquiring bank shareholders as to the value of such mergers/takeovers and also wider concerns about the ensuing reduction of competition and undue concentration in banking markets. Furthermore, a major difficulty in relation to transfers and mergers is the incompatibility between banks' IT systems.

The ex ante planning in the resolution plan should increase the viability of these options. A constant updating of the recovery and resolution plans and the maintenance of a data-room on the bank's assets, liabilities, activities, counterparties and contracts (to determine inter alia the connectedness of a bank to other financial institutions) allow the authorities to make a swift assessment of the situation and also to determine which parts are systemic and which other parts can be hived off. Nevertheless, the authorities may arrive at a point where they have to meet the costs themselves if they want to keep a major systemic bank afloat. In that case, the central bank (liquidity support) and the ministry of finance (capital support) have to do liquidity and capital injections. The tripartite financial stability committee with the supervisor, central bank and ministry is meant to prepare for that in peace time. These committees can be used for drawing up the resolution plans and also to do dry-runs of these plans (crisis simulation exercises).

A horribly thorny issue is how to share the burden (among central banks or ministries of finance) in the case of rescuing a cross-border bank, or other financial institution. As the TARP Congressional Oversight Panel Report (2010) has shown, ${ }^{6}$ in this era of global finance inter-connectedness there is always the possibility that the institutions of a country other than the country providing the rescue money are the main beneficiaries of a rescue operation. Using taxpayers' money in one country to bail out the institutions of another country is an unjust approach and often politically untenable. Thus, a burden sharing solution must be devised to meet this challenge.

An innovation we suggest is to incorporate a proposal for burden sharing in the resolution plan embedded in Living Wills. This would enable burden sharing on an institution by institution basis. ${ }^{7}$ In a well-designed burden sharing system, each country's contribution to the costs (namely, the share in the burden) is aligned with that country's benefits (namely, the maintenance of financial stability). ${ }^{8}$

\footnotetext{
${ }^{6}$ The Report (p.4) notes: "[l]t appears likely that America's financial rescue had a much greater impact internationally than other nations' programs had on the United States. This outcome was likely inevitable given the structure of the TARP, but if the U.S. government had gathered more information about which countries" institutions would most benefit from some of its actions, it might have been able to ask those countries to share the pain of rescue. For example, banks in France and Germany were among the greatest beneficiaries of AIG's rescue, yet the U.S. government bore the entire $\$ 70$ billion risk of the AIG capital injection program. The U.S. share of this single rescue exceeded the size of France's entire $\$ 35$ billion capital injection program and was nearly half the size of Germany's $\$ 133$ billion program."

${ }^{7}$ Although it intends to use different criteria than those suggested in this article, burden sharing on an institution by institution basis is also the approach favoured by the IMF. According to Lipsky (2010): "If we are clear on where the burden ultimately should fall between the private and public sectors, we also need to be clear on burden sharing across countries. We envisage that countries could agree on principles to guide burden sharing that would be applied on an institution-by-institution basis".

8 The IMF (2010b) and the European Commission (2010c) propose to establish ex ante bank resolution funds to be financed through a levy raised on banks. There would, however, be a transitional problem while the resolution funds were initially accumulating levies; what if the crisis came early? Moreover, crises affecting banks are commonly macro-economic and general in nature, following asset market collapses and economic downturns,
} 
The design of the key for sharing the burden should reflect the financial stability benefits. Goodhart and Schoenmaker (2009) discuss two mechanisms. In a first general mechanism, financial stability is assumed to be a truly public good which affects all participating countries. All countries then contribute according to their relative share (for example, relative to GDP). This mechanism is applied by the European Financial Stability Facility for euro-area countries. However, there is no political support for such general burden sharing for banks (Pauly, 2009). Under a second requisite mechanism, financial stability is assumed only to affect those countries where a failing bank is doing business. The burden is financed directly by the countries concerned according to some key reflecting the geographic spread of the business (for example, assets) of the failing bank. Insofar as assets are a good proxy for the real and contagious effects of a bank failure, the specific sharing mechanism will come close to an efficient solution of the coordination problem for bailing out an international bank. Countries facing systemic disruption are asked to contribute. They will do so if the stability effects in their country exceed their contribution.

To be practical, only the countries from the core supervisory college are involved in the resolution plan. A core supervisory college could for resolution purposes turn into a cross-border crisis management group containing the supervisors, central banks and ministries of finance from the core countries. The FSF Principles for Cross-border Cooperation on Crisis Management (Financial Stability Forum, 2009) call for the establishment of firm-specific cross-border crisis management groups composed of representatives from supervisory agencies, central banks and resolution authorities from the key home and host country jurisdictions. According to the FSF, work is underway to promote contingency planning for all major global financial institutions. Meanwhile, within the EU, cross-border stability groups are being established for all major European financial groups (European Union, 2008).

rather than individual and idiosyncratic (Scandinavia rather than Barings). In other words, such crises are not easily diversifiable events, but contagious epidemics. For such reasons resolution funds lack credibility without the ultimate back-up of pledged government support. Resolution funds would therefore only take the issue of burden sharing back one step. In order to establish credible resolution funds, it would be necessary to decide how the burden of meeting shortfalls from the calls upon its funds could be discharged. 
Table 1: Geographical spread of activities of some cross-border banks.

\begin{tabular}{|c|c|c|c|}
\hline \multicolumn{2}{|l|}{ HSBC (2008) } & \multicolumn{2}{|l|}{ Nordea (2007) } \\
\hline Countries & $\begin{array}{c}\text { Distribution } \\
\text { of assets }\end{array}$ & Countries & $\begin{array}{c}\text { Distribution } \\
\text { of assets }\end{array}$ \\
\hline $\begin{array}{ll}\text { Europe } \\
-\quad \text { UK } \\
\text { - } \quad \text { France } \\
\text { - } \quad \text { Rest of Europe } \\
\text { Asia } \\
\text { - } \quad \text { Hong Kong } \\
\text { - } \quad \text { Rest of Asia-Pacific } \\
\text { Americas } \\
\text { - USA } \\
\text { - Rest of Americas } \\
\text { Total }\end{array}$ & $\begin{array}{r}52 \% \\
36 \% \\
13 \% \\
2 \% \\
\\
24 \% \quad \\
13 \% \\
11 \% \\
\\
24 \% \quad \\
17 \% \\
7 \% \\
100 \%\end{array}$ & $\begin{array}{l}\text { Nordic countries } \\
-\quad \text { Denmark } \\
-\quad \text { Finland } \\
-\quad \text { Norway } \\
-\quad \text { Sweden } \\
\text { Rest of Europe } \\
\text { Rest of the World }\end{array}$ & $\begin{array}{r}99 \% \\
26 \% \\
32 \% \\
13 \% \\
28 \% \\
\\
1 \% \\
\\
\end{array}$ \\
\hline Santander (2007) & & Unicredit (2007) & \\
\hline Countries & $\begin{array}{l}\text { Distribution } \\
\text { of assets }\end{array}$ & Countries & $\begin{array}{c}\text { Distribution } \\
\text { of assets }\end{array}$ \\
\hline \begin{tabular}{ll}
\multicolumn{2}{l}{ Western Europe } \\
- & Spain \\
- & UK \\
- & Portugal
\end{tabular} & $\begin{array}{r}75 \% \\
49 \% \\
22 \% \\
4 \%\end{array}$ & \begin{tabular}{ll}
\multicolumn{2}{l}{ Western Europe } \\
- & Italy \\
- & Germany \\
- & Austria
\end{tabular} & $\begin{array}{r}79 \% \\
42 \% \\
25 \% \\
12 \%\end{array}$ \\
\hline Rest of Europe & $8 \%$ & Rest of Europe & $18 \%$ \\
\hline Rest of the World & $17 \%$ & Rest of the World & $3 \%$ \\
\hline Total & $100 \%$ & Total & $100 \%$ \\
\hline
\end{tabular}

Source: Annual Reports 2007-2008.

An illustrative example of the impact of burden sharing on the bailout cost is Nordea. Table 1 shows the geographical spread of activities of Nordea and some other large cross-border banks. As full burden sharing across the EU, or even at the wider global level, is politically not feasible at this stage, a start could be made among more likeminded countries at the regional level (Dermine and Schoenmaker, 2010). To illustrate the working of institution by institution burden sharing, Dermine and Schoenmaker (2010) use the equity-to-GDP ratio (based on book value) as an indicator of the unexpected losses that could arise and of the subsequent public bailout costs. Applying this indicator, Sweden faces a potential bailout cost for Nordea of 5.3\% of its GDP (2007 figures). Under a burden sharing system of the core countries, the four Nordic countries (Denmark, Finland, Norway, and Sweden) split the bill almost equally $(26 \%, 32 \%, 13 \%$ and $28 \%$; see Table 1). Burden sharing would thus substantially reduce Sweden's share from $5.3 \%$ to $1.5 \%$ of its GDP. 
The preparation of a burden sharing arrangement in a resolution plan could strengthen the cohesion in the core supervisory college. As each core country may have to pay up, it has an incentive to make sure that supervision is properly done to minimise the possibility of failure. So the host supervisors with the biggest contingent exposure will be induced by their governments to fully and actively participate in the supervisory college of a particular bank. In that way, the urgency for making a periodic joint assessment of the soundness of this particular bank by all relevant supervisors will increase. Therefore, ex ante burden sharing arrangements diminish the possibility of supervisory forbearance or supervisory free riding, in the case of cross-border institutions. Faced with the possibility that some of the fiscal burden would fall on their own countries' taxpayers, home and host supervisors would be more willing to take preventive action.

\section{Making Resolution Regimes Compatible}

\subsection{Overview}

Resolution regimes and deposit insurance schemes are typically designed to deal with domestic failures. A general issue is whether bank resolution is based on general corporate insolvency law ${ }^{9}$ or on a special resolution regime which ensures higher speed of procedures. The UK, for example, implemented a special bank resolution regime to increase the range of options for the authorities and to speed up the process. Similarly, deposit insurance schemes are currently updated to allow for the swift payout to depositors, when needed. The USA sets an ambitious standard with payouts by the Federal Deposit Insurance Corporation (FDIC) within 2 business days of the failure, while the European Commission (2010d) is aiming for a payout period of one week.

A challenge for the failure of a cross-border bank is the incompatibility of national insolvency regimes. There are different approaches. Under the territorial approach, each country resolves the domestic parts of a cross-border bank within its borders. This basically boils down to ring-fencing the assets within the country. This is the approach adopted in the USA. Under the universal approach, the institution as a whole, that is including its foreign branches (but not subsidiaries), is resolved across borders. This was the approach adopted in the EU by the Winding up Directives. ${ }^{10}$ But even in countries which follow the universal approach, each authority may pursue its own national interests in a crisis (Basel Committee, 2009; Herring and Carmassi, 2010). These different approaches are clearly not compatible. The resolution part of Living Wills will make these inconsistencies very evident thereby strengthening the urge to tackle them ex ante.

\footnotetext{
${ }^{9}$ According to the CEPS Report (2010) and the authors' questionnaire survey of $\mathrm{G} 20$ countries' resolution regimes for financial institutions, most EU countries apply ordinary insolvency procedures (with modifications) and corporate bankruptcy rules to failing banks. However, the number of EU jurisdictions adopting either special resolution regimes or giving resolution powers to the supervisory authorities is on the rise.

${ }^{10}$ EC Directive (2001/24/EC) on the reorganisation and winding up of credit institutions and EC Directive (2001/17/EC) on the reorganisation and winding up of insurance undertakings. Both Directives are currently under review.
} 


\subsection{Suspension of Shareholders' Voting Rights}

The first challenge regulators face in this context is how to ensure that national regimes consistently uphold the principle that losses must first fall on shareholders, until these are wiped out. To achieve this goal Living Wills should provide for a modification of the bylaws (namely, corporate charters) of financial institutions which are subject to Living Wills, in particular suspending shareholders' voting rights, in the event of the institution's failure and its entering into the special resolution process. Relevant modification may take place in the context of general corporate restructuring triggered by Living Wills. To safeguard shareholders' rights, an institution's failure - normally a state where a financial institution is no longer able to support its operations and honour its obligations through the use of own means, in compliance with the terms of its regulatory licence - and entering into the resolution process would have to be clearly defined. In most jurisdictions a company's bylaws (its articles of incorporation or company statute) has contractual force in the way it binds shareholders to the company. Therefore, shareholders would be deemed to have consented in advance and be contractually bound to accept the said suspension of their voting rights, when they subscribe to, buy from the secondary markets, or hold shares in institutions subject to Living Wills. As a result, the risk of shareholder litigation and its potential to disrupt the orderly resolution of the subject institution would be minimized. ${ }^{11}$

This modification would indeed infringe on shareholders' property rights but limitations imposed on all kinds of property rights are not without precedent in most developed countries' legal orders. In fact, property rights in the modern world may be subject to a host of limitations grounded on superior public interest. For instance, property rights may be subject to compulsory acquisition orders for planning purposes. The only difference here is that shareholders would not be entitled to compensation for the appropriation of their voting rights, a waiver to which shareholders will have agreed in advance by subscribing to, buying, or holding equity stakes in financial institutions which have to draw up Living Wills.

Furthermore, such modification of bank shareholder rights in the context of banks in distress is far from unprecedented. In Germany, Hungary, Romania, and Estonia some form of limitation of shareholder voting rights or right to receive dividend is already in place in the case where a bank enters the pre-insolvency or insolvency stage (EU Commission, 2010b: pp. 99-102). Moreover, under the already discussed double liability regime for bank capital, all shareholders of a bank in distress were legally required to provide further payment equal to the initial par value of the shares (Goodhart, 2010). Finally, the contingent convertibility bonds that have been suggested by academic experts, which will be used to boost equity ratios in the event of a substantial fall in bank's market price (Flannery, 2005; Kashyap, Rajan and Stein, 2008), are also prejudicial to pre-existing bank shareholders. Old shareholders' stake in the bank is automatically diluted when the bonds are converted into equity following the trigger of the prescribed contingency.

\footnotetext{
${ }^{11}$ Fear of shareholder litigation disrupted the Fortis resolution (Claessens et al., 2010).
} 
If a provision for the suspension of shareholders' voting rights is enshrined in the institution's bylaws, shareholders should be able to price the risk of their investment in advance and ask for a premium to subscribe or hold shares in a bank or another financial institution in a way that reflects the institution's riskiness. The consequences of the implementation of this proposal are far reaching. First, holders of equity in such financial institutions should expect no private gain by relying on the public guarantee that financial sector institutions enjoy, even in the event that an institution does prove to be 'too-big-tofail'. As a result, this reform would greatly strengthen market discipline and reduce moral hazard. Second, the cost of equity capital for financial institutions subject to Living Wills would become somewhat higher reflecting their increased riskiness. This may impede their growth and restrict their role as the principal development engine of modern economies. Therefore, adoption of the above proposal by the G20 countries would signal their unwillingness to subsidise bank capital any longer and perhaps accept, in exchange, slightly lower rates of economic growth.

\subsection{Effective Cross-border Bank Resolution}

The second challenge relates to the international coordination and effective implementation of crossborder bank resolutions. Given the marked inability of supervisors to co-ordinate their rescue operations during the 2008 crisis (for example, Fortis, Lehman (Claessens et al., 2010)), incompatibility of national resolution regimes and of insolvency procedures entails serious dangers in the case of SIFls operating on a cross-border basis. An example of the difficulties that may be encountered in the context of a cross-border bank resolution is the conflict of powers over asset transfers which in some jurisdictions are vested with the insolvency authorities and in others with the courts (CEPS 2010).

In the light of the recent crisis, many countries are in the process of widening or introducing special laws covering the process of resolution of systemic banks. The UK introduced, for example, a Special Resolution Regime for banks in March 2009 (Avgouleas, 2009; Tucker, 2009). We suggest a further widening of these arrangements to include all systemic financial institutions and not just banks. The 2007-2009 financial crisis showed that non-bank financial institutions can also be systemic and, therefore, they had to receive capital support (notably insurance companies such as AIG and AEGON).

The principal question that arises in this context is whether this window of opportunity to integrate the legal basis for the resolution of SIFIs across all developed countries (notably the G-20 countries) can be properly utilized. As a contribution to the debate we consider the possibility of a standard insolvency model for systemically important financial institutions (SIMSIFI) that could be implemented through legislation in the G-20 countries. ${ }^{12}$ SIMSIFI based harmonisation would modify but not

\footnotetext{
12 Like others, we do not provide a list of systemically important financial institutions, as explained in footnote 5. The Financial Stability Board was reported to have prepared such a list. For legal purposes, however, a fully
} 
impede the powers of the $\mathrm{FDIC}^{13}$ or of deposit insurance schemes in other countries, since it is neutral regarding the institutional form of the resolution authority. Coordinated action in cross-border resolution and harmonisation of national resolution regimes is also the approach favoured by the IMF (IMF 2010a; Strauss-Kahn 2010, Lipsky 2010) and the new Geneva Report (Claessens et al., 2010). We have provided a first outline of such a standard insolvency model in Avgouleas et al. (2010).

Inevitably, a SIMSIFI would be a special regime (a so called lex specialis) with respect to general insolvency laws. Such a regime should be introduced into national legal orders by means of special legislation to ensure that it will not be vulnerable to legal challenge before national courts. Such special legislation need not necessarily be by means of a difficult to agree upon international Treaty. It could be implemented through co-ordinated legislative reform in the G 20 countries. According to Lipsky (2010), the IMF intends to suggest an international framework for regulatory co-operation in the event of the insolvency of a cross-border SIFI: The IMF does not indicate by which means this framework will be implemented into national legal orders and complied with by national authorities and the SIFls. Therefore, our proposal to use Living Wills for this purpose would close a clear conceptual and practical gap in this area. EU policy makers seem to share this view (EU Commission, 2011).

We suggest that a very instructive and useful example of such a special regime is the ISDA master agreement and its close-out netting clauses, ${ }^{14}$ which provide a mechanism for the reduction of credit exposure in the markets. The EU has passed legislation which recognises all transactions concluded under the ISDA architecture as a single agreement and gives force (in part) to ISDA close-out netting clauses, overriding traditional insolvency ${ }^{15}$ and property law requirements. ${ }^{16}$

The first challenge the SIMSIFI must address is how to secure the ordinary substitution or liquidation of the various contractual relationships of the failing institution avoiding at the same time the risk of fire-sales (Schleifer and Vishny, 2010). This is especially important with respect to the closing or substitution of such institution's outstanding derivatives contracts where a hasty closure of the position may disrupt the market and reduce the value of the failing institution's assets (Huertas, 2010).

specified list is needed. It should be ex ante clear to which institutions the Standard Insolvency Model would apply.

${ }_{13}$ Title II of the Dodd-Frank Wall Street Reform and Consumer Protection Act (2010) introduces a new federal receivership process pursuant to which the FDIC may serve as receiver for large, interconnected financial companies whose failure would pose a significant risk to the financial stability of the USA (Act $\S 204(a)$ ). The decision to place such companies into receivership is made by the Secretary of the Treasury after consultation of the FDIC (or in the case of a covered broker-dealer, the SEC, and, in the case of an insurance company, the Director of the Federal Insurance Office) and the Federal Reserve Board of Governors.

${ }_{14}$ Under the ISDA Master Agreement the failure of party A to make a payment required in the context of transactions between the parties, concluded under the ISDA contractual framework, or the bankruptcy of party A, gives party $B$ the right to terminate all outstanding transactions. Following that termination, the ISDA Master explicitly allows for close-out netting, namely, the process under which obligations arising from simultaneously terminated transactions are netted to a single settlement amount, which, naturally, is much smaller than the gross exposures of each party to the other.

${ }^{15}$ To give full force to the close-out netting clauses under the ISDA Master Agreement, ISDA drafted a Model Act on Close-Out Netting in 2006, lobbying national authorities to adopt it. Most developed countries have introduced legislation to enable or strengthen close-out netting.

${ }^{16}$ The Collateral Directive (2002/47/EC) renders inapplicable certain provisions of Member States' insolvency law that would, inter alia, inhibit the effective realisation of financial collateral in the context of bilateral close-out netting. 
To avoid this risk the SIMSIFI may provide for a period of five working days, extended in exceptional circumstances (for example, a very hard to value and illiquid portfolio of assets) to ten working days, during which all obligations of the failing institution are 'frozen'. This gives 'breathing space' to the resolution authorities and insolvency officials to wind down relevant contracts in an orderly manner minimizing systemic risk and the losses of the failing institution and of its counterparties.

Even so, Living Wills will not prove as effective as intended in the absence of a mechanism that extends parent insolvency proceedings to local and foreign subsidiaries, which are dependent on the parent for their continuous operation as a going concern, or vulnerable in the event of parent failure. In general, subsidiaries do not seem able to survive the failure of the parent, as was the case with Kaupthing Bank of Iceland, when their continuous solvency and liquidity is dependent on parent guarantees and/or provision of standby credit lines. However, even where subsidiaries are ringfenced, they may still prove unable to survive the failure of the parent, due to the effects of reputation contagion. Namely, their business standing is very likely to be contaminated by parent failure. In this case, the subsidiary will be hit by collapsing confidence in its solvency and continuous operation. Uninsured depositors may rapidly demand their deposits back, or, as was the case with Lehman Brothers, foreign subsidiaries of a failing institution may face a market reluctance to provide them with short-term credit, making them illiquid (see also section 2). As result of such market developments, the subsidiary might not be able to carry on as a going concern, on a standalone basis, forcing the subsidiary or its supervisors to initiate a transfer of assets to a third party purchaser, a temporary nationalisation, or the commencement of insolvency proceedings.

Moreover, in many cases the business of the group is integrated and subsidiaries' assets are treated as group assets. Thus, it may not be possible to separate them in insolvency. This is especially the case where corporate separateness has been created merely in order to facilitate the regulation and supervision of the subsidiary by home or host state regulators (Herring and Carmassi 2010). In those cases it is clearly unfair to creditors that no pooling of assets is allowed between local and international corporate members of the same financial group. In addition, in such cases, it is doubtful how effective the re-organisation of a parent financial institution in insolvency may be, if domestic and foreign subsidiaries are ignored.

Finally, ring-fencing may prove costly and complicating, instead of simplifying, cross-border group resolutions. The segregation of intra-group internal funding and liquidity flows will create operating inefficiencies and may amplify rather than resolve the problem of cross-border bank failures and even impose extra costs on a host country's economy (CEPS, 2010; Cerutti et al., 2010).

Yet, there is currently no internationally agreed framework dealing with financial group resolution on a cross-border basis (Basel Committee, 2009) and the powers of resolution authorities over other entities of the same group in the event of a financial institution's insolvency are often unclear or very limited. Therefore, there is an overriding public interest, which includes concerns for the protection of 
confidence in the fairness of the financial system (Herring, 2010), in favour of giving supervisors the option of extending the SIMSIFI to domestic and foreign subsidiaries of a failing parent company. This extension of the Standard Insolvency Model also provides a powerful incentive for the group to simplify its corporate structure. The data room, as described in the previous section, would enable the administrator / liquidator to track a financial group's assets as well as its creditors. Once the SIMSIFI regime would be triggered, all claims against the financial group in difficulties should go through this regime.

However, such a proposal could create serious opposition from supervisors. In the absence of a clear framework for sharing the burden for the resolution of a cross-border financial group (as proposed in section 3) and for safeguarding the equal treatment of domestic and foreign creditors, supervisors will find it hard to extend the universal approach, especially to subsidiaries established cross-border. The supervisors of the foreign subsidiary may lack confidence in the insolvency proceedings held in another jurisdiction, be unable to enforce foreign judgments, or may just be concerned to protect domestic creditors' interests. Furthermore, this proposal goes counter to the traditional legal doctrine of separateness of incorporation, which certain jurisdictions, such as the UK, hold sacred in the event of the bankruptcy of a group entity, even when there are strong arguments in favour of lifting the corporate veil (for example, Adams v. Cape Industries plc [1990] Ch 433). In other jurisdictions, such as the USA, intra-group pooling of assets ('substantive consolidation') is allowed by bankruptcy courts, ${ }^{17}$ but the conditions under which 'substantive consolidation' is allowed remain unclear.

Germany, on the other hand, has a fully developed law on corporate groups since the German Stock Corporation Act 1965 (Aktiengesetz). The Act shows in many areas little 'respect' for the principle of separateness of incorporation, but it only applies to corporate groups (Konzernrecht) comprising public companies and does not extend to non-public companies. Under German law on corporate groups, in the event of insolvency proceedings, the parent may be made liable for the debts of the subsidiary. Influenced by Germany law, Hungary also regards companies within a group as closely interlinked economic entities (European Commission, 2010b, pp. 109-112). There are also certain jurisdictions, such as Italy, which allow for co-ordinated resolution proceedings for the subsidiaries of failing banks within the same jurisdiction, although pooling of assets is not allowed. In the UK under the Special Resolution Regime created by the Banking Act 2009, the resolution authorities may extend their resolution powers to the holding company of a failing bank (Article 82 of the Banking Act 2009).

However, in the majority of EU member states bank parent and subsidiary companies are treated as separate legal entities and authorities need to initiate separate resolution and insolvency proceedings

\footnotetext{
${ }^{17}$ In the USA 'substantive consolidation' comes from 'federal common law' permitting a bankruptcy court to treat a group of affiliated companies as if they are one, merging their assets and liabilities for purposes of the bankruptcy proceedings. Essentially, US bankruptcy courts use their general 'equity powers' provided in section 105 of the Bankruptcy Code to order 'substantive consolidation' (11 U.S.C.A. § 105). Courts may even merge assets of non-bankruptcy affiliates with those of bankruptcy affiliates if the court finds that substantive consolidation is required.
} 
for each of them (European Commission, 2010b, pp. 109-112). Of course, in the EU these difficulties may be overcome through the enactment of harmonisation legislation that recognises the concept of "banking group", as described in the EU Commission's proposal ${ }^{18}$ and makes it part of any crossborder resolution arrangements. Also, at the wider global level, UNCITRAL recommendations for cross-border insolvencies (UNCITRAL, 2009) are a very useful guide in extending insolvency proceedings to group entities.

Any extension of the Standard Insolvency Model to group entities other than the failing institution, especially group entities located in other jurisdictions, and the 'pooling of assets' would require: (a) a burden sharing mechanism, (b) an agreed framework for the recognition of foreign insolvency proceedings and foreign decisions, and (c) a mechanism for the identification of domestic and foreign subsidiaries which may be included in bankruptcy proceedings in the event of parent failure. On (a), we discuss a way to structure a burden sharing mechanism in the previous section. On (b), Avgouleas et al. (2010) provide an outline of a mechanism for the recognition of foreign insolvency proceedings, which should be based on mutual recognition. On (c), the inclusion of domestic and foreign subsidiaries in insolvency proceedings should be based on the contractual approach. Namely, the institution subject to a Living Will should agree ex ante with the college of supervisors which of its domestic and foreign subsidiaries are dependent on the continuous operation of the parent as a going concern or vulnerable to parent failure, and thus insolvency proceedings concerning the parent company should also extend to those subsidiaries.

Finally, a bank's Living Will should specify the relevant deposit insurance arrangements for its depositors. Deposit insurance schemes are typically run along national lines. Most depositors of international banks fall under the respective deposit insurance scheme of their country of domicile. However, cross-border branches fall under the home country deposit insurance scheme in the EU. The legal obligation under the Deposit Guarantee Schemes Directive (94/19/EC) is clear: the home country deposit guarantee scheme should cover the depositors in the home country as well as depositors in cross-border branches. Nevertheless, the Icelandic authorities chose to give priority to Icelandic depositors over the UK and Dutch depositors after the failure of several Icelandic banks in 2008. This highlights concerns about the stability and viability of deposit guarantee schemes and the role that Living Wills may have to play in this area.

\section{Conclusion}

In most large developed countries, the group of identified systemic financial intermediaries is virtually identical with the group of cross-border financial intermediaries. So when a situation arises to rescue,

\footnotetext{
${ }^{18}$ The European Commission has consulted on the issue of "banking group" and cross-border (intra-group) asset transfers (European Commission, 2009). The Commission proposals have drawn qualified support from the IMF. Nonetheless, the IMF, like the Commission itself, is concerned about the impact of relevant legal modifications on the principle of separateness of incorporation (IMF, 2010a). In addition, a legal study, ordered by the Commission, has highlighted the many obstacles that exist under member states' law in the context of intra-group asset transfers (European Commission, 2010a).
} 
resolve, or force into liquidation a systemic financial institution in difficulty, the same situation will usually require the authorities to handle similar problems at the cross border level. Yet when there was a need for such resolution in the recent crisis, for example, Lehman Brothers, Fortis, Dexia, the Icelandic banks, the authorities, almost without exception, acted purely on the basis of narrow national interest. Moreover, when such institutions were saved (Bear Stearns, AIG, HBoS, RBS, Irish banks, etc.), the rescue was done entirely by the home country (and its taxpayers) with no contribution at all from host countries who nevertheless benefited from the absence of adverse externalities / spill-overs. Even after this experience, however, the tendency in most countries seeking to introduce special resolution regimes for such systemic financial institutions by new legislation has been to craft the proposed Bills as if all such resolution requirements were purely a domestic problem. For example, little notice of cross border problems has been taken in the Dodd-Frank Wall Street Reform and Consumer Protection Act of 2010.

This gross incompatibility between the (global) economic reality of integrated cross-border markets and the fragmented national regulatory / legal reform attempts represents a glaring weakness of the world's financial system. It should not be allowed to persist. The purist solution of a single world financial supervision and bank resolution authority is unattainable for the foreseeable future. Proposals to limit cross-border problems by making all systemic branches / subsidiaries into standalone separate entities completely controlled by their host regulator are generally unacceptable, especially in the EU. They will also create serious operating and financial inefficiencies and lead to global market fragmentation.

Living Wills will force each cross-border SIFI to have an ex-ante resolution programme, agreed amongst the authorities of the countries concerned. Thus, Living Wills are the most suitable and (most widely accepted) instrument of international regulatory cooperation in the case of cross-border SIFIs. For this reason, we suggest that among the main elements of the resolution programme incorporated in a Living Will should be: (a) arrangements to share the fiscal burden between home and host countries in the case that an institution (or parts of it) is rescued; and (b) a common insolvency framework in the case that a SIFI (or parts of it) is put into liquidation. The incorporation of the above recommendations would also strengthen the ex post effect of Living Wills, as burden sharing and resolution procedures are bound to be among the biggest and least predictable obstacles that resolution authorities will face when dealing with a cross-border SIFI in distress.

A major barrier, to a harmonization exercise, however, is the mosaic of different legal structures, controlling bank insolvencies, in all such countries. However, the adoption of Living Wills by G20 countries opens a window of opportunity for drastic regulatory reform in the complex area of bank insolvency and resolution. The case for consistent cross-border regimes has been put with emphasis from all corners of the global regulatory system. Organisations, like the IMF and the European Commission, and individual countries within and outside the G20 now see the clear need for new and revised legislation to cover insolvencies of systemically important financial institutions. 
Should we not then take this opportunity to integrate bank insolvency laws in all major countries through harmonised legislation? There are precedents; the acceptance by the law of many countries of the close-out netting clauses of an ISDA Master agreement for settling outstanding derivative contracts in the event of one of the parties' failure to make a payment or its entering into bankruptcy provides a very instructive template. Nevertheless, the development and acceptance of a standard insolvency model for systemically important financial institutions (SIMSIFI) would be a daunting exercise fraught with coordination difficulty and domestic resistance. It would require a large number of countries with strong and varied legal traditions and systems to introduce significant changes in their legal structures, which are the product of historical evolution shaped by domestic economic concerns and the prevailing legal culture. We provide the outline of such a standard insolvency model in this article. We recommend further empirical research surveying the relevant laws of the G20 jurisdictions.

\section{Acknowledgements}

The authors would like to thank for valuable comments Richard Herring, Patricia McCoy, Rosa Lastra and participants in seminars and workshops at the Wharton School, Duisenberg School of Finance and Cardozo Law School. 


\section{References}

Admati, A. and P. Pfleiderer (2010), 'Increased-Liability Equity: A Proposal to Improve Capital Regulation of Large Financial Institutions', Stanford University Graduate School of Business Research Paper No. 2043.

Arner, D. and J. Norton (2009), 'Building a Framework to Address Failure of Complex Global Financial Institutions', Hong Kong Law Journal 39:95-128.

Avgouleas, E. (2009), 'Banking Supervision and the Special Resolution Regime of the Banking Act 2009: The Unfinished Reform', Capital Markets Law Journal 4, 201-235.

Avgouleas, E., C. Goodhart and D. Schoenmaker (2010), 'Living Wills as a Catalyst for Action', Duisenberg School of Finance Policy Paper No 4.

Basel Committee on Banking Supervision (2009), 'Report and Recommendations of the Cross-border Bank Resolution Group', Basel.

Basel Committee on Banking Supervision (2010), 'Basel III: A Global Regulatory Framework for More Resilient Banks and Banking Systems', Basel.

Centre for European Policy Studies (2010), 'Overcoming Too Big to Fail - A Regulatory Framework to Limit Moral Hazard and Free Riding in the Financial Sector', Report by the CEPS-Assonime Task Force on Bank Crisis Resolution, Brussels.

Cerutti, E., A. Ilyina, Y. Makarova, and C. Schmieder (2010), 'Bankers Without Borders? Implications of Ring-Fencing for European Cross-Border Banks', IMF Working Paper No WP/10/247.

Claessens, S., R. Herring and D. Schoenmaker (2010), 'A Safer World Financial System: Improving the Resolution of Systemic Institutions'. 12th Geneva Report on the World Economy, International Center for Monetary and Banking Studies, Geneva, and CEPR, London.

Dermine, J. and D. Schoenmaker (2010), 'In Banking, Is Small Beautiful?' Financial Markets, Institutions \& Instruments 19, 1-19.

Dowd, K. (1992), The Experience of Free Banking, London: Routledge.

European Union (2008), 'Memorandum of Understanding on Cooperation between Financial Supervisory Authorities, Central Banks and Finance Ministries of the European Union on CrossBorder Financial Stability', Brussels.

European Commission (2009), 'An EU Framework for Cross-Border Crisis Management in the Banking Sector', European Commission Communication COM(2009) 561/4, Brussels.

European Commission (2010a), 'Study on the Feasibility of Reducing Obstacles to the Transfer of Assets within a Cross border Banking Group During a Financial Crisis, Brussels.

European Commission (2010b), 'Study on Pre-insolvency - Early intervention - Reorganization Liquidation', Brussels.

European Commission (2010c), 'Bank Resolution Funds', European Commission Communication $\operatorname{COM}(2010) 254$ final. Brussels.

European Commission (2010d), 'Proposal for an EU Directive Guarantee Schemes (recast)', $\operatorname{COM}(2010)$ 369, Brussels.

European Commission (2011), 'Working Document: Technical Details of A Possible Framework for Bank Recovery and Resolution' IP/11/10 Brussels. 
Financial Services Authority (2009). 'A Regulatory Response to the Global Banking Crisis: Systemically Important Banks and Assessing the Cumulative Impact', Discussion Paper 09/4, London.

Financial Stability Forum (2009), 'FSF Principles for Cross-border Cooperation on Crisis Management', Basel.

Flannery, M. (2005), 'No Pain, No Gain? Effecting Market Discipline via Reverse Convertible Debentures', in: H. Scott (ed.), Capital Adequacy Beyond Basel: Banking, Securities, and Insurance,. Oxford: Oxford University Press, pp. 171-196.

Freshfields Bruckhaus Deringer (2003), 'Study on Financial Conglomerates and Legal Firewalls', London: Freshfields Bruckhaus Deringer.

Goodhart, C. (2010), 'Are CoCos from Cloud Cuckoo-Land?', VoxEU, June 10.

Goodhart, C. and D. Schoenmaker (2009), 'Fiscal Burden Sharing in Cross-Border Banking Crises', International Journal of Central Banking 5, 141-165.

Herring, R. (2010), 'Wind-Down Plans as an Alternative to Bailouts: The Cross-Border Challenge',. In: K. Scott, G. Shultz, and J. Taylor (eds), Ending Government Bailouts as We Know Them, Stanford: Hoover Institution Press, pp. 125-162.

Herring, R. and J. Carmassi (2010), 'The Corporate Structure of International Financial Conglomerates, Complexity and Its Implications for Safety and Soundness'. in: A. Berger, P. Molyneux and J. Wilson Oxford Handbook of Banking, Oxford: Oxford University Press, pp. 173204.

Huertas, Thomas (2010), Crisis: Cause, Containment and Cure, Palgrave Macmillan.

Jones, D. and K. King (1995), 'The Implementation of Prompt Corrective Action: An Assessment', Journal of Banking and Finance 19, 491-510.

International Monetary Fund (2010a), 'An EU Framework for Cross-Border Crisis Management in the Banking Sector', IMF Staff Contribution to the European Commission Consultation. Washington D.C.

International Monetary Fund (2010b), 'A Fair and Substantial Contribution by the Financial Sector', Final Report for the G-20, Washington D.C.

Kuritzkes, A., T. Schuermann and S. Weiner (2003), 'Risk Measurement, Risk Management, and Capital Adequacy in Financial Conglomerates'. In: R. Herring and R. Litan (eds), BrookingsWharton Papers on Financial Services: 2003, Washington D.C.: Brookings Institution, pp. 173204.

Kashyap, A., R. Rajan, and J. Stein (2008), 'Rethinking Capital Regulation', Kansas City Symposium on Financial Stability.

Kydland, F. and E. Prescott (1977), 'Rules Rather than Discretion: The Inconsistency of Optimal Plans', Journal of Political Economy 85, 473-492.

Lastra, R. and R. Olivares-Caminal (2009), 'Cross-Border Insolvency: The Case of Financial Conglomerates', in: J. LaBrosse, R. Olivares-Caminal and D. Singh (eds), Financial Crisis Management and Bank Resolution, London: Informa UK Ltd, pp. 262-289. 
Lipsky, J. (2010), 'Towards an International Framework for Cross Border Resolution', Remarks delivered at the ECB and its Watchers Conference XII, Frankfurt.

Mevorach, I. (2010), 'Towards a Consensus on the Treatment of Multinational Enterprise Groups in Insolvency', Cardozo Journal of International and Comparative Law, forthcoming.

Pauly, L. (2009), 'The Old and the New Politics of International Financial Stability', Journal of Common Market Studies 47, 955-975.

Schleifer, A. and R. Vishny (2010), 'Asset Fire Sales and Credit Easing', American Economic Review 100, 46-50.

Schoenmaker, D. and S. Oosterloo (2008), 'Financial Supervision in Europe: A Proposal for a New Architecture', in: L. Jonung, C. Walkner and M. Watson (eds), Building the Financial Foundations of the Euro - Experiences and Challenges, London: Routledge. pp. 337-354.

Squam Lake Report (2010), Fixing the Financial System, Princeton: Princeton University Press.

Strauss-Kahn, D. (2010), 'Reject Ad Hoc, National Financial Reforms', Financial Times, February 17.

TARP Congressional Oversight Panel (2010), 'August Oversight Report: The Global Context and International Effects of the TARP', Washington D.C.

Tucker, Paul. 2009. The Crisis Management Menu, Speech at SUERF, CEPS and Belgian Financial Forum Conference on Crisis Management at the Cross-Roads. Brussels, 16 November.

UNCITRAL (2009), Working Group V (Insolvency Law), Thirty-seventh session, UNCITRAL Legislative Guide on Insolvency Law, Part three: Treatment of Enterprise Groups in Insolvency, Note by the Secretariat, 31 August, A/CN.9/WG.V/WP.90.

Westbrook, D. (2009), Out of Crisis: Rethinking Our Financial Markets, New York: Boulder Co: Paradigm Publishers. 